\title{
Confectionery sunflower breeding and supply chain in Eastern Europe $^{\text {品 }}$
}

\author{
Nada Hladni* and Dragana Miladinović \\ Institute of Field and Vegetable Crops, Novi Sad, Serbia
}

Received 23 January 2019 - Accepted 4 April 2019

\begin{abstract}
Growing confectionery sunflower for consumption is becoming more and more attractive in the whole world. In Eastern European countries production, processing, and breeding of confectionery sunflower differ from oil-type sunflower. There is no precise information on the sowing areas of confectionery varieties and hybrids in Eastern European countries, mostly because, in statistical reports, sunflower producers do not provide separate data on the share of varieties in gross revenue of all manufactured products. Confectionery sunflower seeds are used in bakery products, but also in a number of natural health products and healthy snacks, as well as for direct consumption in the hull, dehulled, raw or backed form. Confectionery sunflower breeding is characterized by the fact that different markets have different demands when it comes to the seed size, hull colour, and other traits, which make this process more difficult and costlier. Market demands and production area of confectionery sunflower show a steady increase due to its nutritional value and use in human nutrition. In Eastern European countries, it is expected that the highly productive confectionery hybrids will replace varieties, which will lead to the increase of surfaces under this crop.
\end{abstract}

Keywords: confectionery sunflower / Eastern Europe / production / natural health products

Résumé - Amélioration et chaîne d'approvisionnement de tournesol de confiserie en Europe de l'Est. La cultivation du tournesol de confiserie devient de plus en plus attrayante dans le monde entier. Dans les pays d'Europe de l'Est, la production, la transformation et la sélection du tournesol de confiserie diffèrent de celles du tournesol de type huile. Il n'existe pas d'informations précises sur les zones d'ensemencement des variétés de confiserie et des hybrides dans les pays d'Europe de l'Est, principalement parce que, dans les rapports statistiques, les producteurs de tournesol ne fournissent pas de données distinctes sur la part des variétés dans le revenu brut de tous les produits manufacturés. Les graines de tournesol de confiserie sont utilisées dans les produits de boulangerie, mais également dans un certain nombre de produits de santé naturels et de collations santé, ainsi que pour la consommation directe sous forme de coque, décortiquée, crue ou cuit. La sélection de tournesols de confiserie se caractérise par le fait que les marchés diffèrent en ce qui concerne la taille des graines, la couleur de la coque et d'autres caractéristiques, ce qui rend ce processus plus difficile et plus coûteux. La demande du marché et la superficie de production de tournesol de confiserie sont en augmentation constante en raison de sa valeur nutritionnelle et de son utilisation dans la nutrition humaine. Dans les pays d'Europe de l'Est, les hybrides hautement productifs remplaceront les variétés, ce qui entraînera une augmentation des surfaces sous cette culture.

Mots clés : tournesol de confiserie / Europe de l'Est / production / produits de santé naturels

\section{Introduction}

The genus Helianthus is comprised of a large number of species. Cultivated sunflower, Helianthus annuus L., has two

\footnotetext{
Contribution to the Topical Issue "The oil \& protein crop supply chain in Eastern Europe / La filière oléoprotéagineuse en Europe de l'Est"

*Correspondence: nada.hladni@ifvens.ns.ac.rs
}

main types, the oilseed type and the non-oilseed type also known as confectionery. The agronomic development of sunflower for oil ("oilseed" type) and edible achenes ("confectionary" type) occurred in Eastern Europe and Russia, in the late 1800s (Cronn et al., 1997). Confectionery non-oil sunflower seed types can be black, white, black with white stripes, or colourful and significantly larger than the oil-type sunflower seeds. They have high hull percentage, with thicker hull loosely connected to the kernel, as well as variable seed 
shape. The hull is easily separated from the kernel and allows the seed to be dehulled as a whole (Fernandez-Martinez et al., 2009; Hladni et al., 2012). The most important production criteria for confectionery hybrids which increase their market value are: seed yield, seed protein content, mass of 1000 seeds, hull/kernel ratio and dehullability of the seed.

Confectionery sunflower breeding is mostly similar to oiltype sunflower breeding (Jocić et al., 2015), but there are specific breeding goals for confectionery sunflower (Tab. 1). Breeding of confectionery sunflower is characterized by the fact that different markets have different demands regarding the seed size, hull colour and other traits, which makes this process more difficult and costlier (Hladni, 2016). When creating confectionery hybrids, it is also very important to combine genes responsible for high yield potential and good technical and technological traits of the seed.

Market demands and production area of confectionery sunflower show a steady increase both in the World and in Eastern Europe due to its nutritional value and use in human nutrition.

\section{Current situation in Eastern Europe regarding market demands and production}

Currently, sunflower has become a major commercial crop in Eastern Europe; with leading producers such as Russia, Ukraine, Turkey, Romania, and Bulgaria. Although Eastern Europe is one of the most important producing regions of sunflower seeds, its market demand exceeds production, which provides opportunities for suppliers of other markets. Even though the majority of sunflower seed production is destined for the production of sunflower oil and sunflower meal as a byproduct, the market for confectionery seeds is growing.

The use of confectionery sunflower seeds has a long and rich tradition in Russia, Turkey and Ukraine. The favoured seed colour of confectionery hybrids in Turkey is white with grey stripes, while in Balkan countries such as Serbia, Bulgaria, Moldova, and Romania, as well as Russia black seeds are preferred (Ergen and Saglam 2005; Sincik and Goksoy, 2014). Most customers prefer tasty, high-quality, and longer confectionery type seeds, but preferences differ according to the region or country. For instance, consumers from Turkey, and some other countries require seeds that are at least $2 \mathrm{~cm}$ long, whereas Balkan, Ukraine, and Russia consumers prefer big seeds with big kernels and reduced husk content (Hladni, 2016). In Serbia, domestic and foreign confectionery varieties with large black seeds have been replaced by NS confectionery hybrids such as NS Gricko, NS Slatki, NS Garavi and NS Leviathan that are produced by many small farmers in Serbia. The yield of confectionary hybrids is on the same level as the yield of oil hybrids, over $4 \mathrm{t} / \mathrm{ha}$, with the seed yield after processing of $3.5 \mathrm{t} / \mathrm{ha}$, and the price is significantly higher per $\mathrm{kg}$, sometimes even double, depending on the seed fraction. The processing industry, that is small factories, buys the large fraction seed for backing and packaging.

The world production and market share of large-seed and confectionery sunflower has been increasing steadily for the past 5 years (Hladni et al., 2017). However, there is no precise information on the sowing areas of large-seeded varieties and hybrids of sunflower in Eastern European countries ${ }^{1}$ because the sunflower producers do not provide separate data on the share of such varieties in gross revenue of all manufactured products in statistical reports. In Ukraine, the share of largeseeded varieties and hybrids in the production of sunflower accounts for about $5 \%$ of all sown areas. The growing demand caused the CIS ${ }^{2}$ to increase the share of varieties with a large weight of 1000 seeds in the overall structure of sunflower crops (Ukra Agro Consult, 2014). During the last five years, the production of confectionery sunflower in Russia was about one million hectares annually. This is about $12 \%$ of the total area of sunflower production. Large-seeded open pollinated confectionery varieties are mainly grown in commercial fields in Russia (Demurin, 2018).

The buying price for confectionery type hybrids depends on the seed quality, which is defined by seed size and characteristics of the hull. The quality of confectionery sunflowers is divided into three categories: food-grade, ingredient and birdfeed sunflowers. Food-grade category is made up of the highest quality seeds, including the largest and cleanest seeds. The largest seeds, called "in-hull seeds", are marketed salted, roasted and packaged for human consumption. The largest market for food-grade seeds is consumer retail. Packaged sunflowers are primarily a specialty food product and are sold to consumers as a healthy snack either in the hull or hulled. Ingredient category seeds (medium-size seeds) are seeds that are food-grade quality, but they do not contain the highest quality seeds to be in the food-grade category. Medium-size seeds, called "hulling seeds" are dehulled and the kernels are used, either roasted or not, as a snack food or in a number or confectionery or bakery products. Ingredient sunflowers are sold to firms, such as bread companies, that use sunflower seeds in their products. The sunflower seeds that cannot be used as food ingredients are used for birdfeed. Usually these are smaller, lower quality seeds. (Hofland and Kadrmas, 1989; Lofgren, 1997; De Figueiredo et al., 2011, 2015; AgMRC, 2018).

\section{Confectionery sunflower breeding in Eastern Europe}

The most important criteria for introducing new confectionery sunflower hybrids into production are: protein and seed yield, plant height, head diameter, seed protein content, seed oil content, number of seeds per head, 1000-seed weight, seed size, seed colour, as well as hull-kernel ratio (Pekcan et al., 2015; Hladni et al., 2016). In order to achieve high and stable confectionery hybrid yield it is important to create a model of a sunflower plant which would enable an increase of the number of plants per hectare in the conditions of intensive cultivation practices and mechanized harvesting. Confectionery hybrids have significantly higher seed yield than the open-pollinated varieties, as well as resistance to biotic and abiotic stresses

\footnotetext{
${ }^{1}$ Bulgaria, Serbia, Croatia, Greece, Macedonia, Montenegro, Albania, Bosnia Herzegovina, Moldova, Romania, Russia, Turkey, Ukraine.

${ }^{2}$ Commonwealth of Independent States (Armenia, Azerbaijan, Belarus, Georgia, Kazakhstan, Kyrgyzstan, Moldova, Russia, Tajikistan, Turkmenistan, Ukraine, and Uzbekistan).
} 
Table 1. Specific goals in confectionery sunflower breeding.

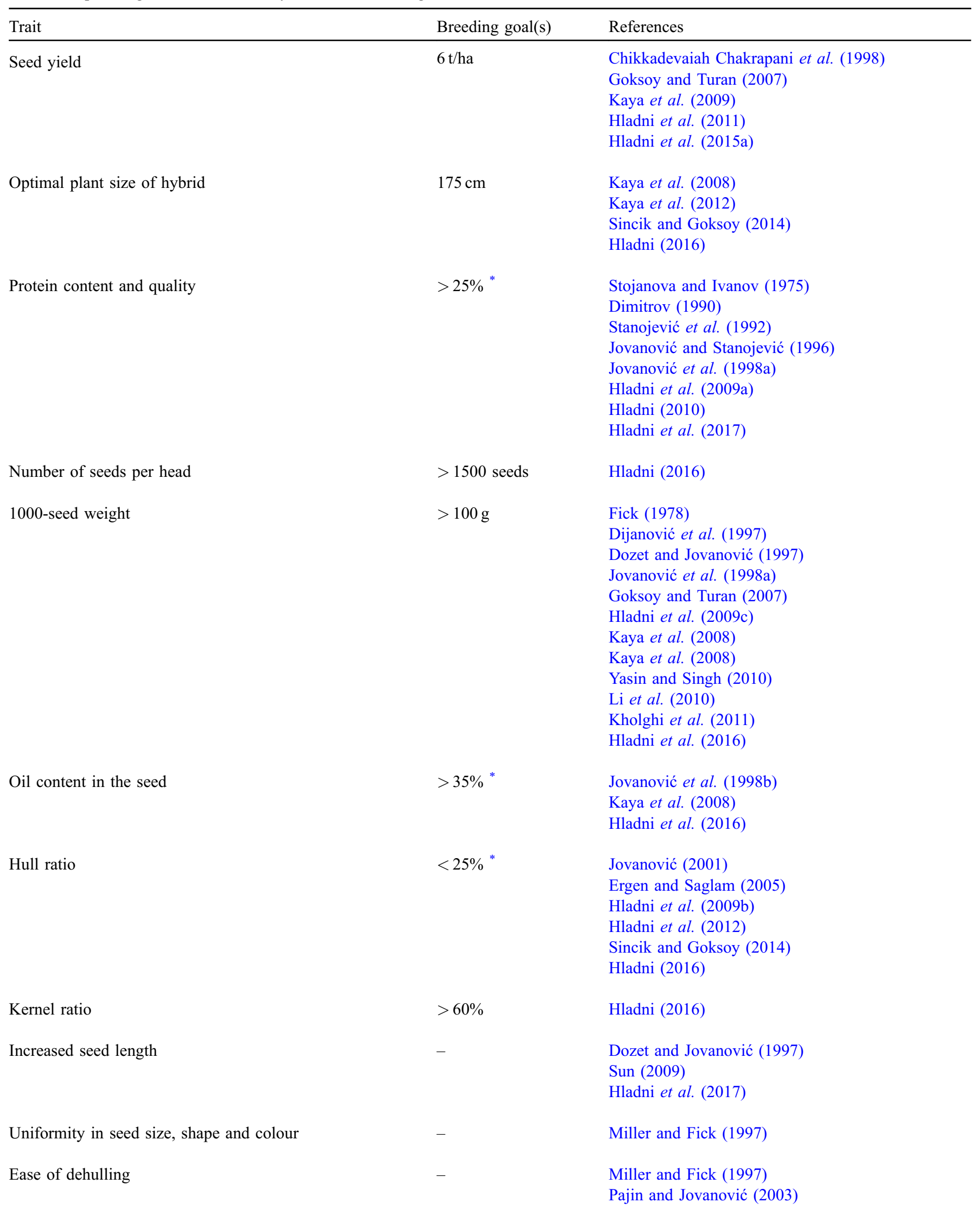


Table 1. (continued).

\begin{tabular}{lll}
\hline Trait & Breeding goal(s) & References \\
\hline Seed quality maintenance in long-term storage & - & Jovanović (2001) \\
Tolerance to dominant diseases & - & Dijanović et al. (2003) \\
& - & Kaya (2010) \\
Tolerance broomrape & & Ephart and Eizenberg (2010) \\
& & Hladni et al. (2018) \\
& & Kaya and Beser (2018) \\
& & Valesco et al. (2018) \\
Duca et al. (2018) & Fernandez-Martinez and Dominques-Jimenez (1981) \\
Tolerance abiotic stress and environmental conditions & - & Gholinezhad et al. (2013) \\
& & Gholinezhad et al. (2014)
\end{tabular}

\footnotetext{
* Calculated on dry matter.
}

(Hladni et al., 2018). The advantages of hybrids in comparison to varieties are also crop uniformity, suitability for mechanized harvesting as well as seed quality. It is expected that confectionery hybrids will continue to spread more in production and eventually replace the varieties (Hladni, 2016). Very important goals in sunflower breeding generally, but also in confectionery type breeding, are the creation of resistance or tolerance of hybrids to diseases, broomrape, and drought and to incorporate herbicide-tolerant traits in the adapted hybrids. The cooperation and exchange of breeding material from different breeding centres, as well as creation of joint hybrids, has gained importance in recent years as a tool for creation of new, more resilient and productive confectionery hybrids, ready to face both challenges from the market and changing climate (Hladni et al., 2018)

In the world, currently, there are not a lot of institutes and companies that have a confectionery sunflower-breeding program. Eastern European public institutes such as Institute of Field and Vegetable Crops (IFVCNS), Serbia; VNIIMK, Russia; Dobrudzha Agricultural Institute (DAI), Bulgaria; Yuryev Plant Production Institute (YPPI), Ukraine; National Agricultural Research and Development Institute (NARDI), Romania; Research Institute for Field Crops ("Selectia"), Moldova; Agricultural Institute Osijek and Trakya Agricultural Research Institute (TARI), Turkey have both public and private sunflower breeding programs for developing confectionery varieties and hybrids, with VNIIMK and IFVCNS having the most advanced breeding programs.

After the demand for confectionery sunflower increased, VNIIMK started a confectionery-breeding program to develop new open-pollinated (OP) varieties and confectionery hybrid breeding program at the end of 20th century. Four OP confectionery varieties were developed: SPK, Lakomka, Borodinskiy, and Oreshek. SPK, Lakomka and Oreshek varieties are classified as intermediates between oil type and confectionary type and only Borodinskiy could be identified as a "classical" confectionary variety. Varieties belong to the maturity group with 110 - to 120-day vegetation period. Intermediate types of seeds have a special Russian name "mezheumok". Their seeds are close to the oil-type but larger in size and 1000-seed weight, with higher hull content and lower oil content. Hull is black or black with grey stripes and could be easily mechanically dehulled (Borodin, 2003; Mamonov, 2004). VNIIMK have also started a new confectionery hybrid-breeding program in 2009 and 2010. The new confectionary inbred lines and hybrids developed were found to be suitable for use both as confectionary and oiltype hybrids. These hybrids have higher seed yield than highoil-content sunflower and higher 1000-seed weight. The most prominent hybrid is Katyusha (Gontcharov and Beresneva, 2011; Gontcharov, 2012). New directions of breeding of confectionery varieties are associated with the development of high-oleic, imidazolinone and tribenuron-methyl resistant genotypes (Demurin, 2018).

Confectionery sunflower breeding program has been established at IFVCNS in mid-1990s with the aim of developing modern confectionery open-pollinated hybrids. Within the breeding program for confectionery sunflower special attention is directed towards: creating hybrids depending on different market demands ${ }^{3}$; purpose and manner of usage, for human nutrition or bird feed; different production conditions for classical or organic production. The NS Confectionery hybrids registered in Serbia, EU and Russia are: NS Gricko, NS Slatki and NS Leviathan etc. Characterized by decreased seed oil content and increased seed protein content, the NS confectionery hybrids respond profoundly to production and markets demands of EU, Russia and Balkan countries. Their placement continues in the Iranian, Albanian and Chinese markets.

Other institutes have confectionery sunflower breeding programs mostly aimed at creation of new open-pollinated hybrids, although the varieties still have important place in some countries. All programs aim to decrease dependence on the imports and satisfy specific demands regarding seed colour.

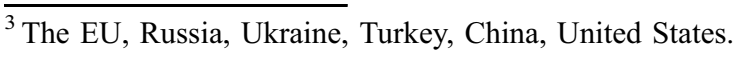




\section{Confectionery sunflower production practices in Eastern Europe}

When it comes to production practices and technologies used in production, there are not many differences between oil and confectionery hybrids. Both the oilseed type and the nonoilseed sunflower types are short-season crops that can be grown over a wider range of latitudes compared to the other oilseed crops. They have a deep root system that allows them to flourish in rotations that maximize water use from the soil. Both crops can tolerate drought better than most other field crops but requires properly prepared soil starting with primary tillage performed in autumn instead of spring (Terzić et al., 2017). The primary rotation system in Eastern Europe is sunflower-wheat, with higher use of mechanization and decreased need for workers that led to lower production costs and higher profitability (Kaya et al., 2008).

Based on our research, it is extremely important to honour the crop rotation for confectionery sunflower along with the sowing deadlines, the sowing norms that can be found on the back of seed packages. The importance of crop rotation in confectionery sunflower is especially visible in dry years. It should return to the same parcel every four years and should not come after soy or rapeseed. Another important step in confectionery sunflower growing is to find the minimal crop density in order to get the seed that is large enough with the appropriate mass of 1000 seeds, without significant lowering of yield. Based on a three-year trial on NS confectionery hybrids, the optimal density is $42-46000 \mathrm{plant} / \mathrm{ha}$. In Turkey, larger seeds could also be obtained by irrigation (or ample rain during the growing period) in normal row planting $(70 \times 40 \mathrm{~cm})$, or decreasing plant population per hectare, especially in normal rain-fed areas. For instance, confectionery sunflower is cultivated at $1 \mathrm{~m} \times 50 \mathrm{~cm}$ with only 20000 plants per hectare in order to obtain larger seed size in fallow areas of the Middle Anatolia region in Turkey. (Kaya, 2004). Low crop density was also found to have positive effect on seed protein content (Balalić et al., 2016).

Confectionery sunflower has larger seeds and needs to be sown a bit deeper than the oil sunflower (for the oil sunflower the recommendation is $3-5 \mathrm{~cm}$, and for confectionery $5-7 \mathrm{~cm}$ ). Sowing season is usually during March and April and harvest begins at the end of August and continues through October. Based on the research performed over several years in trials at IFVCNS and data collected from the producers using NS hybrids, in Serbia, the optimal sowing period for confectionery sunflower is the second and third tenth of April. This is a bit later in comparison to the oil ones, for which the optimal period is the last tenth of March or the first one in April, when the soil temperature is around $8-10^{\circ} \mathrm{C}$. If the confectionary sunflower is sown up to that period there are no significant drops in yield, however if you move it to the beginning of May, there is significant drop in yield. What is specific for growing confectionery sunflower is that the big producers perform the harvest when the seeds have low moisture content, $<9 \%$, and that the seed is sent to processing immediately after the harvest. Since the seed size defines confectionery sunflower quality and price, special attention is paid to separation of the seeds by their size during processing (Shevchenko and Aliiev, 2018).

\section{Main producers of confectionery sunflower in Eastern Europe}

\subsection{Russia}

Russia has the largest sunflower planting areas in the world. Major regions of sunflower growing are North Caucasus, Volga, and Central Black Earth. The Volga district is one of the most important agricultural regions in Russia due to higher yield potential and production for many grain crops (USDA, 2013). Currently sunflower is one of the most profitable crops in Russia due to its high price and increased demand. Consequently, planting areas have been gradually increasing in the last decade, although sunflower production is still greatly dependent on weather in spring and changes from year to year. Considering confectionery sunflower, openpollinated varieties with special Russian name "mezheumok" cover more than 700000 ha. Commercial success of confectionery OP varieties led to appearance of confectionery hybrid breeding programs (Gontcharov, 2016).

Consumers in Russia prefer seeds of OP varieties for the direct consumption. The seeds also have to be easily dehulled by the machinery for confectionery use. The achenes of these OP varieties are of an intermediate type between confectionery and oilseed hybrids. The weight of thousand achenes of these varieties is $100-120 \mathrm{~g}$; the oil content is $45-47 \%$, and the hull content $28-30 \%$ at a plant density of 40000 plants per hectare.

\subsection{Ukraine}

Ukraine is one of the main world producers of sunflower seed and sunflower by-products, becoming a significant supplier for the global market. Ukraine is ranked second in sunflower planted areas, after Russia, with $21 \%$ of total sunflower world planted area. It is also the leader of sunflower seed production, producing $24 \%$ of total sunflower seed in the world. Sunflower seed production is especially attractive to Ukrainian farmers due to greater export opportunities and lower production costs compared with other crops in the rotation. Confectionery sunflower segment is about $3-5 \%$ of the total production of sunflower seed. A new trend in the market stimulates the creation and introduction of confectionery sunflower hybrids. Confectionery sunflower is mainly cultivated in Zaporizhia, Kherson, Dnipropetrovsk, Poltava, Mykolaiv, Donetsk regions. A number of farms, for many years already, specialize in the cultivation of large-seeded and confectionery sunflower, on the parcels of 300-1000 ha. Confectionery sunflower, grown in Ukraine, is consumed in the domestic market, as well as exported. However, an accurate estimate of the volume of exports is not possible to define, as products do not have separate HS code. According to market operators, about $35-40 \%$ of the seeds produced in Ukraine are exported. The main export destinations are the CIS countries, the EU, Canada, and the USA (Ukra Agro Consult, 2014).

In Ukraine, confectionery sunflower is required to have 1000 -seed weight more than $100 \mathrm{~g}$ and calibrated sunflower seed 34+, 36+, 38+, 40+ (Ukra Agro Consult, 2014). A decade ago, the most common confectionery sunflower was Donskoy which has the 1000 -seed mass $140 \mathrm{~g}$ and thick hull. This variety is in high demand in countries such as Romania, 
Bulgaria and Poland. In recent years Lakomka has become a more popular variety, with 1000 -seed mass of $115-120 \mathrm{~g}$, and has surpassed Donskoy in taste and yield. It is quite common in Georgia, Armenia, along with the Baltic States and in Europe. In addition to these two varieties, Zaporizhia Confectionery and Turkish White are also popular for production in Ukraine (Ukra Agro Consult, 2014).

\subsection{Turkey}

Turkey is one of the main world producers of confectionery sunflower seed with the total cultivation area of confectionery sunflower of 104992 and 35783 ha of this cultivation area is in Central Anatolia. Confectionery sunflower production and planted areas were doubled in the last ten years. (Day and Kolsarici, 2016). It is an important cash crop due to its use for human consumption and birdfeed (Day and Kolsarici, 2016). In the Middle Anatolia Region (Ankara, Kirikkale, Konya, Aksaray, Kirsehir, Kayseri, etc.) confectionery sunflower makes more than half of the areas under sunflower are $(61 \%)$. Turkey is also one of the biggest confectionery sunflower consumers in the world. Hence, local confectionery sunflower production is not enough for Turkey consumption and domestic market is also supplied by importing similar confectionery sunflower types.

Landraces and OP confectionery varieties are mainly used in confectionery sunflower production in Turkey (Tan and Tan, 2010). These local varieties and village populations usually have lower seed quality, they are branched and tall with small heads like wild-type sunflower. Confectionery sunflower is grown under irrigated or rainfed conditions in Anatolia. However, farmers do not get higher yields even under irrigated conditions, due to not using certified and high-quality seed. (Day and Kolsarici, 2016). The main reason for the prevalent use of landraces and OP varieties is that there is a low production of certified seeds with desired quality. The landraces or local varieties are not suitable for the harvesting with combines because of their non-uniformity during plant development in the field (Tan and Tan, 2010; Tan et al., 2016). Landraces and OP varieties have huge genetic variation and are well adapted to local soil types and climatic conditions, as well as other environmental factors. They are the source of many desirable genes, especially those addressing higher adaptability to environmental conditions and resistance to certain diseases (Kaya, 2015). Broomrape is the biggest issue in the Trakya region. Weed control and some diseases, such as downy mildew, Sclerotinia, Macrophomina, and so forth are also important, problems for Turkish sunflower production in recent years. Broomrape affects Turkish sunflower production not only in the Trakya region, but also in other regions such as the Black Sea, Cukurova, and Middle Anatolia (Kaya, 2010).

\subsection{Other countries}

Confectionery sunflower production and use is also growing largely in other countries such as Moldova, Serbia, Greece and Croatia. Serbia is one of the leading countries in the Balkan Region both in production and the breeding of confectionery sunflower. The percentage of confectionary sunflower hybrids in total area sown to this crop in Serbia is rather small (5-10\%) (Jocić et al., 2015). In Serbia, large OP confectionery varieties have been grown but in the last few years they have been replaced by NS confectionery hybrids which keep spreading. In Romania, confectionery hybrids are produced, but not enough to meet the consumption demand. There are many small factories for dehulling and for packing sunflower seeds. Much of the confectionery type sunflower seed is imported from Bulgaria, Turkey or Spain (Pacureanu, 2018). Albania, Macedonia, Bosnia and Herzegovina and Montenegro have rather low areas with sunflower and small production of confectionery sunflower.

\section{Present status and future directions of confectionery sunflower breeding and production in Eastern Europe}

Production of confectionery sunflower shows a steady increase due to its nutritional value and use in human nutrition (Hladni et al., 2017). It is expected that a highly productive confectionery hybrids will replace varieties, which will lead to the increase of surfaces under confectionery sunflower (Hladni, 2016). Within the breeding program for confectionery sunflower, special attention needs to be directed towards creating hybrids for different types of consumption and production depending on the demands of the Eastern European market. Breeding programs should find solutions for empty and under-developed seeds, especially in the centre of the flower head, high husk percentage in kernels, and decreased dehullability. Due to changes in climate and spreading of growing area, identification of drought tolerant genotypes became another important goal in confectionary sunflower breeding. This also stands for the length of vegetation, with need to create hybrids with different vegetation seasons - early (80-90 days), medium early (90-100 days) and medium late (100-115 days) (Hladni, 2016). As the length and thickness of seed were found to be the most important traits affecting 1000seed weight, these traits should be more intensively used for the improvement of seed yield and evaluation of sunflower breeding materials (Hladni et al., 2016; Pérez-Vich et al., 2018). Furthermore, newly developed confectionary hybrids should have higher yield capacity and larger seeds with higher oleic acid and vitamin $\mathrm{E}$ (tocopherol) content to increase the nutritional value and shelf-life of seeds (Kaya et al., 2012).

One of the biggest problems in confectionary sunflower breeding today is the narrow genetic variability. Creation of joint hybrids is the only way to overcome this concern. The continued creation of new confectionery hybrids with increased genetic potential for seed and protein yield, protein content, resistance to pathogens and herbicides will allow more efficient use of genetic resources of the confectionary population in the breeding programs. The exchange of confectionery genotypes i.e. lines could enable creation of joint hybrids tested for yield and technical-technological characteristics of seed in different agroecological production conditions. Testing confectionery sunflower under different production systems (classical or organic) can be useful in identifying hybrids with broad adaptability (Hladni et al., 2015 b, c). Rapid changes in broomrape race composition have forced sunflower breeders and geneticists to not only search for genes for resistance to the new races of Orobanche but to also 
look for alternative solutions to the problem of broomrape control. The development of confectionery sunflower hybrids resistant to the imidazolinone herbicides has made it possible to successfully control broomrape regardless of its race composition.

\section{Conclusion}

High-protein sunflower has a separate market from the oiltype sunflower. Accurate surface and yield information cannot be found in most of national and international statistic data. In comparison to the oil type, presence of confectionery sunflower in Eastern Europe is significantly smaller, although it is present in all the counties where sunflower is successfully grown. In the past decade confectionery sunflower has become an essential part of human nutrition and diet programs. Increased application of proteins in the food industry imposes new goals in breeding, such as changes in the fatty acid composition and tocopherol content in confectionary hybrids. Introducing new confectionary hybrids into production will contribute to increased and stable seed and protein yield and enable an increase of the number of plants per hectare in the conditions of intensive cultivation practices and mechanized harvesting. The advantage of confectionery sunflower hybrids in comparison to varieties are crop uniformity, suitability for mechanized harvesting, optimal plant density for achieving the desired size, seed quality, colour suitability and higher seed yield than the open pollinated varieties. It is expected that confectionery hybrids will continue to spread more in production and replace the varieties. Confectionery hybrids exhibit adaptability to both conventional and organic cultivation thus being convenient for satisfying the increased demand of for organic food. Having all this in mind it is to be expected that the surfaces under confectionery sunflower in Eastern Europe will continue to grow due to its increased usage in human nutrition, introduction of high yielding hybrids and increased processing capacities.

Acknowledgements. The research in this paper was financed with the support from IFVCNS and Ministry of Science, Education and Technological Development of the Republic of Serbia, project TR31025.

The authors are grateful to Dr Sreten Terzić, Dr Vladimir Miklič and Dr Siniša Jocić for their valuable comments regarding the content of this paper, and MA Marija Hladni for her editing of the English language in the paper.

\section{References}

AgMRC. 2018. Available from https://www.agmrc.org/commoditiesproducts/grains-oilseeds/sunflower-profile (last consult: 2018/12/ 20).

Balalić I, Crnobarac J, Miklič V, Radić V. 2016. Seed yield and protein content in sunflower depending on stand density. Matica Srpska J Nat Sci Novi Sad 130: 93-103.

Borodin SG. 2003. Sunflower OP varieties breeding for specific use. In: Proceedings of International Conference devoted to 90 years of VNIIMK, Krasnodar, Russia, pp. 15-25 (in Russian).

Chikkadevaiah Chakrapani Y, Jagannath DP, Ramesh S. 1998. Evaluation of sunflower genotypes for confectionery purpose. Helia 21: 131-136.
Cronn R, Brothers M, Klier K, Bretting P, Wendel J. 1997. Allozyme variation in domesticated annual sunflower and its wild relatives. Theor Appl Genet 95: 532-545.

Day S, Kolsarici O. 2016. Interactive effects of different intra-row spacing and nitrogen levels on yield and yield components of confectionery sunflower (Helianthus annuus L.) genotype (Alaca) under Ankara conditions. Int J Dev Res 6: 10285-10290.

De Figueiredo AK, Baümler E, Riccobene IC, Nolasco SM. 2011. Moisture-dependent engineering properties of sunflower grains with different structural characteristics. J Food Eng 102: 58-65.

De Figueiredo AK, Rodríguez LM, Riccobene IC, Nolasco SM. 2015. Analysis of the performance of a dehulling system for confectionary sunflower. Seeds Food Nutr Sci 5: 541-548.

Demurin Y. 2018. Breeding of confectionery sunflower varieties in VNIIMK. In: Proceedings of Symposium on Confection Sunflower Technology and Production, Inner Mongolia, China, pp. 66-67.

Dijanović D, Stanković V, Jovanović D. 1997. Testing of hybrid combination of protein-type sunflower. In: Proceedings of 38 th Meeting Oilcrops Production and Processing, Budva, Montenegro, pp. 242-245 (in Serbian).

Dijanović D, Stanković V, Mihajlović I. 2003. Improvement of sunflower for consumption. Genetika 35: 161-167.

Dimitrov S. 1990. High-protein sunflower variety Obitel. Zemedelie 86: 31-32.

Dozet B, Jovanović D. 1997. Combination ability and mode of inheritance of seed size in $F_{1}$ generation of confectionary sunflower [Helianthus annuus var. macrocarpus Dc (Ck11)]. Sel Seed Prod 3-4: 20-25.

Duca M, Clapco S, Nedealcov M, Dencicov L. 2018. Influence of environmental conditions on the virulence and distribution of Orobanche cumana Wallr. in the Republic of Moldova. OCL 26 (1): 3 .

Ephart JE, Eizenberg H. 2010. Quantification of the dynamics of Orobanche cumana and Phelipanche aegyptiaca parasitism in confectionery sunflower. Weed Res 50: 140-152.

Ergen Y, Saglam C. 2005. Yield and yield characters of different confectionary sunflower varieties in conditions of Tekirdag. $J$ Tekirdag Agric Fac 2: 221-227.

Fernandez-Martinez J, Dominques-Jimenez J. 1981. Sunflower breeding for drought resistance. In: Proceedings of EUCARPIA Symposium: Sunflower Breeding, Prague, Czech Republic, pp. $138-147$.

Fernandez-Martinez JM, Perez-Vich B, Velasco L. Sunflower. In: Vollmann J, Rajčan I, eds. Oil crops: Handbook of plant breeding. The Netherlands: Springer, 2009, pp. 155-232.

Fick GN. Sunflower breeding and genetics. In: Carter JF, ed. Sunflower science and technology, Agronomy Monography 19. The USA: ASA, CSSA y SSSA, 1978, pp. 279-337.

Gholinezhad E, Darvishzadeh R, Bernousi I. 2013. Effects of drought stress on grain qualitative traits in Iranian confectionary sunflower (Helianthus annuus L.) landraces. Iran J Genet Plant Breed 2: 9-20.

Gholinezhad E, Darvishzadeh R, Bernousi I. 2014. Evaluation of drought tolerance indices for selection of confectionery sunflower (Helianthus annuus L.) landraces under various environmental conditions. Not Bot Horti Agrobot Cluj-Napoca 42(1): 187-201.

Goksoy AT, Turan ZM. 2007. Correlations and path analysis of yield components in synthetic varieties of sunflower (Helianthus annuus L.). Acta Agron Hung 55(3): 339-345.

Gontcharov SV. 2012. Hybrid sunflower breeding in VNIIMK (Russia). In: Proceedings of the 18th International Sunflower Conference, Mar del Plata \& Balcarce, Argentina, $160 \mathrm{p}$. 
Gontcharov SV. 2016. Confectionery sunflower hybrid breeding in VNIIMK (Russia). In: Proceedings of 19th International Sunflower Conference, Edirne, Turkey, pp. 327-330.

Gontcharov SV, Beresneva ND. 2011. Confectionary hybrid sunflower breeding in Russia. J Agric Sci Technol B1: 919-924.

Hladni N. 2010. Genes and sunflower yield. Monograph. Serbia Beograd: Foundation Andrejević, 116 p.

Hladni N. 2016. Present status and future prospects of global confectionery sunflower production. In: Proceedings of 19th International Sunflower Conference, Edirne, Turkey, pp. 45-59.

Hladni N, Jocić S, Miklič V, Radić V, Radeka I, Lečić N. 2009a. Borneo-New NS sunflower confectionary type hybrid. Sel Seed Prod 15(4): 63-73.

Hladni N, Jocić S, Miklič V et al. 2009b. The evaluation of values of new confectionary sunflower hybrids. In: Proceedings of 50th Meeting Oilcrops Production and Processing, Herceg Novi, Montenegro, pp. 57-61 (in Serbian).

Hladni N, Jocić S, Miklič V et al. 2009c. Test results for new experimental hybrids of confectionary type during 2007 and 2008. Ratar Povrt 46(I): 385-392.

Hladni N, Jocić S, Miklič V, Saftić-Panković D, Kraljević-Balalić M. 2011. Interdependence of yield and yield components of confectionary sunflower hybrids. Genetika 43(3): 101-114.

Hladni N, Miklič V, Jocić S, Jocković M, Radeka I, Lečić N. 2012. Determining the influence of yield components on the confectionary sunflower seed yield. In: Proceedings of 53rd Conference of Oil Industry. Production and Processing of Oilseeds, Herceg Novi, Montenegro, pp. 55-62.

Hladni N, Jocić S, Mijić A, Miklič V, Miladinović D. 2015a. Correlation and path coefficient analysis for protein yield in confectionary sunflower (Helianthus annuus L.). Genetika 47(3): 811-818.

Hladni N, Jocić S, Miklič V, Miladinović D. 2015b. The possibility of growing confectionery sunflower under the conditions of organic production system. In: Proceedings of 2th International Conference on Plant Biology and 21st Symposium of the Serbian Plant Physiology society, Petnica, Serbia, $22 \mathrm{p}$.

Hladni N, Miklič V, Jocić S, Miladinović D, Sakač Z. 2015c. Confectionery sunflower under conventional and organic production systems. In: Proceedings of II. International Plant Breeding Congress and EUCARPIA Oil and Protein Crops Section Conference, Antalya, Turkey, 161 p.

Hladni N, Jocić S, Miklič V, Miladinović D, Zorić M. 2016. Interrelationship between 1000 seed weight with other quantitative traits in confectionary sunflower. Ekin J Crop Breed Genet 2 (1): 51-56.

Hladni N, Terzić S, Mutavdžić B, Zorić M. 2017. Classification of confectionary sunflower genotypes based on morphological characters. J Agric Sci 155: 1594-1609.

Hladni N, Miklič V, Jocić S et al. 2018. In: Proceedings of Symposium on Confection Sunflower Technology and Production, Inner Mongolia, China, pp. 79-80.

Hofland C, Kadrmas N. 1989. Confection sunflower handbook. 2nd Edition. Bismarck, ND (USA): National Sunflower Association.

Jocić S, Miladinović D, Kaya Y. Breeding and genetics of sunflower. In: Martínez-Force E, Turgut Dunford N, Salas JJ, eds. Sunflower chemistry, production, processing, and utilization. The USA: AOCS Press, 2015, pp. 1-26.

Jovanović D. 2001. Possibilities of using sunflower and breeding for specific purposes. Ratar Povrt 35: 209-221.

Jovanović D, Stanojević D. 1996. Sunflower breeding for increased protein content in the seed. In: Proceedings of 37th Meeting
Oilcrops Production and Processing, Budva, Montenegro, pp. 223-241 (in Serbian).

Jovanović D, Škorić D, Dozet B. 1998a. Confectionery sunflower breeding. In: Proceedings of 2nd Balkan Symposium on Field Crops, Novi Sad, Yugoslavia, pp.349-352.

Jovanović D, Škorić D, Dozet B. 1998b. Confectionery sunflower breeding for a long shelf life of kernel. In: Proceedings of EUCARPIA International Symposium on Breeding of Protein and Oil Crops, Pontevedra, Spain, pp. 149-151.

Kaya Y. 2004. Sunflower breeding, seed industry and future directions in Turkey. In: Proceedings of 16th International Sunflower Conference, Fargo, North Dakota, pp. 465-472.

Kaya Y. 2010. Public sunflower breeding in Turkey and future directions. Plant Sci 47: 7-13.

Kaya Y. Sunflower. In: Gupta SK, ed. Breeding oilseed crops for sustainable production. UK: Elsevier, 2015, pp. 55-82.

Kaya Y, Beser N. 2018. Confectionery sunflower hybrid breeding studies in Turkey: Current and future strategies. In: Proceedings of Symposium on Confection Sunflower Technology and Production, Inner Mongolia, China, pp. 551-552.

Kaya Y, Evci G, Pekcan V, Gucer T, Yilmaz IM. 2008. Yield relationships in confectionery sunflower (Helianthus annuus L.). In: Proceedings of the Annual Conference Agricultural Machinery and Technologies, Agricultural Sciences and Veterinary Medicine, Repair and Reliability, Rousse, Bulgaria, pp. 7-11.

Kaya Y, Evci G, Durak S, Pekcan V, Gucer T. 2009. Yield components affecting seed yield and their relationships in sunflower (Helianthus annuus L.). Pak J Bot 41(5): 2261-2269.

Kaya Y, Jocić S, Miladinović D. Sunflower. In: Gupta SK, ed. Technological innovations in major world oil crops. The USA: Springer Press, 2012, pp. 85-129.

Kholghi M, Bernousi I, Darvishzadeh R, Pirzad A. 2011. Correlation and path-coefficient analysis of seed yield and yield related traits in Iranian confectionery sunflower populations. Afr J Biotechnol 10: 13058-13063.

Li S, An Y, Guo S, Nie H, Zhang M. 2010. Analysis on hereditary variation, correlation and principal components of main agronomic characters in confectionary sunflower. Heilongjiang Agric Sci 2010(9): 7-10.

Lofgren JR. Sunflower for confectionary food, bird food, and pet food. In: Schneiter AA, ed. Sunflower technology and production, Agronomy Monograph. The USA: American Society of Agronomy, 1997, pp. 747-764.

Mamonov AI. 2004. Development of initial breeding material of confectionery and oil-type sunflower with big seed size. NTB VNIIMK 132: 39-41.

Miller JF, Fick GN. Genetics of sunflower. In: Schneiter AA, ed. Sunflower technology and production, Agronomy Monograph. The USA: American Society of Agronomy, 1997, pp. 441-495.

Pacureanu MJ. 2018. Sunflower seed production and processing in Romania. In: Proceedings of Symposium on Confection Sunflower Technology and Production, Inner Mongolia, China, pp. 70-71.

Pajin B, Jovanović O. 2003. Dragee product based on sunflower. Acta Period Technol 34: 13-21.

Pekcan V, Evci G, Yilmaz I, Kaya Y. 2015. Developing confectionery sunflower hybrids and determination of their yield performances in different environmental conditions. Ekin J Crop Breed Genet 1 (2): 47-55.

Pérez-Vich B, Aguirre MR, Guta B, Fernández-Martínez JM, Velasco L. 2018. Genetic diversity of a germplasm collection of confectionery sunflower landraces from Spain. Crop Sci 58(5): 1972-1981. 
Shevchenko I, Aliiev E. 2018. Study of the process of calibration of confectionery sunflower seeds. Food Sci Technol 12(4): 135-142.

Sincik M, Goksoy AT. 2014. Investigation of correlation between traits and path analysis of confectionary sunflowergenotypes. Not Bot Horti Agrobot Cluj-Napoca 42: 227-231.

Stanojević D, Nedeljković S, Jovanović D. 1992. Oil and protein concentration in seed of diverse high-protein inbred lines of sunflower. In: Proceedings of the 13th International Sunflower Conference, Pisa, Italy, pp. 1263-1268.

Stojanova J, Ivanov P. 1975. Inheritance of oil and protein content in first hybrid progeny in sunflower. Rastenievud nauka 12(9): 30 35 (in Bulgarian).

Sun Y. 2009. Genetic analysis of important traits for confectionery sunflower in Australia. Ph.D. Thesis, School of Land, Crop and Food Sciences, The University of Queensland, Brisbane, Australia.

Tan AS, Tan A. 2010. Sunflower (Helianthus annuus L.) landraces of Turkey: Their collection, conservationand morphometric characterization. Helia 33: 55-62.
Tan AS, Altunok A, Aldemir M. 2016. Oilseed and confectionary sunflower (Helianthus annuus L.) landraces of Turkey. In: Proceedings of the 19th International Sunflower Conference, Edirne, Turkey, pp. 556-566.

Terzić S, Miklič V, Čanak P. 2017. Review of 40 years of research carried out in Serbia on sunflower pollination. OCL 24(6): D608.

U.S. Department of Agriculture (USDA). 2013. Available from http:// www.thecropsite.com/reports (last consult: 2018/12/20).

Ukra Agro Consult. 2014. Available from https://www.apk-inform. com/en/subscription/agrimonth (last consult: 2018/12/20).

Valesco L, Fernadez-Martinez J, Perez-Vich B. 2018. Sunflower broomrape: Problems and solutions for a global threat. In: International Proceedings of Symposium on Confection Sunflower Technology and Production, Inner Mongolia, China, pp. 25-26.

Yasin AB, Singh S. 2010. Correlation and path coefficient analyses in sunflower. J Plant Breed Crop Sci 2(5): 129-133.

Cite this article as: Hladni N, Miladinović D. 2019. Confectionery sunflower breeding and supply chain in Eastern Europe. OCL 26: 29. 